\title{
Public-Private Partnership in Handling Corona Virus Disease 2019 in DKI Jakarta Province
}

\author{
${ }^{1}$ Dwiky Lucky Adiyasha, Izzatusholekha
}

\author{
1'Universitas Muhammadiyah Jakarta, Indonesia; dwikylucky9834@gmail.com
}

Received: July 8, 2021; In Revised: November 24, 2021; Accepted: December 27, 2021

\begin{abstract}
The increase in confirmed cases of COVID-19 requires the DKI Jakarta Provincial Government to partner with stakeholders such as the private sector, companies, and the public in handling COVID-19 in DKI Jakarta Province. This research focuses on the partnership between the DKI Jakarta Provincial Government and the non-profit Human Initiative and Agile Innovation Labs companies. This study aims to describe and analyze public-private partnerships in handling COVID-19 in DKI Jakarta Province. This study uses a qualitative approach with a descriptive method, in the analysis of this study using the theory of public-private partnership proposed by Yusuf et al. (2006) with three major factors, namely: (1) process factor, (2) partner factor, and (3) structural factor. The following data were analyzed for study: interviews, observations, and documentation reviews conducted at the Regional Cooperation Bureau, DKI Jakarta Province's Secretariat. The results show that a public-private partnership relationship produces various benefits for each party. However, there are still obstacles, such as changing officials in policymaking agencies without a proper transfer of knowledge from their predecessors, which may hamper the partnership process.
\end{abstract}

Keywords: Public-Private Partnership, Covid-19, DKI Jakarta Province

\section{Introduction}

Various countries worldwide are currently facing the spread of what was later named the Corona Virus Disease 2019 (Covid-19). This disease spreads throughout the world in an infectious manner, namely an infection that spreads in a network like the flu (Mona, 2016). The increase in the addition of confirmed cases of COVID-19 in a short time, of course, requires fast handling. The spread of COVID-19 is straightforward and can infect anyone regardless of age (Mona, 2020). The reach and spread of this disease have spread throughout the world, so COVID-19 has been declared a world pandemic (World Health Organization, 2019). The status of a global pandemic or epidemic indicates that the spread of COVID-19 is happening so fast that no country in the world can avoid it.

The Indonesian government has issued various regulations for handling the COVID-19 pandemic. The step for managing COVID-19 is enacting Presidential Decree No. 7 of 2020 concerning the Task Force for the Acceleration of Handling Corona Virus Disease 2019 (Covid19). This Presidential Decree is proof of the seriousness of the Indonesian government in increasing its readiness and ability to prevent, detect, and respond to the COVID-19 pandemic (Hukumonline.com, 2020). 
Figure 1

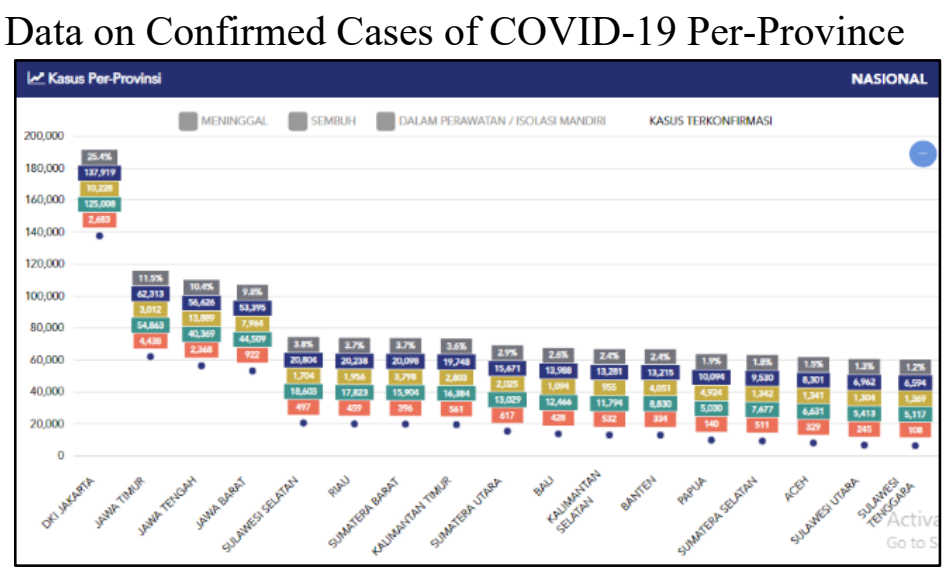

Source: covid19.go.id (last updated 05/12/2020)

More than half of the positive confirmed cases of COVID-19 in Indonesia are concentrated on the island of Java. Data from Figure 1.3 shows that in October 2020, the number of confirmed positive for COVID-19 nationally was 349,260, and 204,291 of them were on the island of Java. That means that residents of the Indonesian island of Java account for 59.03 per cent of the positive confirmed cases of COVID-19. In addition, it turns out that the positive confirmed cases of COVID-19 on the island of Java are concentrated in urban areas. Three provinces on the island of Java are ranked in the top three as the provinces with the highest number of confirmed positive cases of COVID-19.

Ranked first in the national province with the highest number of confirmed positive cases of COVID-19 is the Special Capital Region of Jakarta. As quoted from covid.go.id (2020), it is known that the positive confirmed cases of COVID-19 in DKI Jakarta Province are 26.02 per cent of the national percentage. And apparently, this percentage is higher than the sum of the rates of the other two highest provinces. The number of positive confirmed cases in DKI Jakarta Province is 90,266 , far adrift from East Java, with 47,894 cases, and West Java, with 28,529 cases.

The Province of the Special Capital Region of Jakarta is the epicentre of the spread of COVID-19 in Indonesia (https://regional.kontan.co.id/23/06/2020). This is because Jakarta is the country's capital city, which is a transit point for various citizens from remote parts of the country to travel to foreign countries. In addition, DKI Jakarta Province is a metropolitan area with various complex problems before the outbreak of the COVID-19 pandemic in Indonesia, such as the problem of population density. The scope of DKI Jakarta Province is 662.3 square $\mathrm{km}$ with 10.5 million people. With a dense population, where in general the population density in DKI Jakarta Province reaches 15,663 people per square km, the spread of COVID-19 is faster, and the number of cases is increasing significantly in DKI Jakarta Province (Badan Pusat Statistik, 2018).

In the initial observation, there were three (3) causes for the high number of confirmed positive cases of COVID-19 in DKI Jakarta Province. The first reason is that, so far, the testing capability carried out by the DKI Jakarta Provincial Government can be said to be good. This means that many positive confirmed cases of COVID-19 have been detected. Furthermore, it has been recorded that the number of people who PCR tested in the past week was 91,303 people. In comparison, WHO's minimum target for testing capability in DKI Jakarta Province 
every week was 10,645 people (corona.Jakarta.go.id: 15/10/2020).

The second reason is the high number of positive cases or the percentage of positive cases in the last week in DKI Jakarta Province, namely 8.4 per cent. The accumulated percentage of positive cases in total is 8.3 per cent. Meanwhile, WHO has set a minimum limit of 5 per cent positive rate or ratio of positive cases in DKI Jakarta Province (corona.Jakarta.go.id: 15/10/2020). This means, with increased testing capabilities that have exceeded the target, the more people who are tested, the more people will be detected with confirmed COVID-19 because the positive rate is still high.

Furthermore, the third cause, supervision of treatment or care, especially supervision of self-isolated patients, is still weak. Supervision carried out by officers in the field is not carried out in total, so it is possible for patients who are confirmed positive for COVID-19 to selfisolate, travel outside the house and become carriers or transmit Covid-19 to those around them. In addition, no regulations govern the implementation of technical self-isolation. This makes patients who are confirmed positive for COVID-19 self-isolated from receiving strict sanctions if they violate the self-isolation protocol provided by the DKI Jakarta Provincial Government.

Given some of the issues discovered, the DKI Jakarta Provincial Government cannot work alone. From various aspects of confirmed cases of COVID-19, the role of local governments is the most critical factor in handling COVID-19 cases in their regions. This, of course, requires a variety of solutions that involve various parties. Nevertheless, the problem of COVID-19 is a common problem. Normative mechanisms and processes will undoubtedly find it difficult to answer this question. Therefore, all parties, starting from the government and the public and private sectors in the DKI Jakarta Province, must collaborate to deal with the COVID-19 pandemic.

Therefore, different handling of COVID-19 is needed. First, it is vital to involve stakeholders. Government officials at all levels have the opportunity to collaborate with the private sector to achieve public goals more effectively than governments alone can (Donahue and Zeckhauser, 2011). This is in line with what Ansell and Gash (2008) stated that the government can involve non-government stakeholders in solving a public problem. This shows that in government administration, public actors such as the government, non-governmental institutions, both private and non-governmental organizations (NGOs), and the community are not separate things and work independently; on the contrary, they work together for the common good.

Coping with Corona Virus Disease 2019 (Covid-19) in DKI Jakarta Province can be analyzed using the concept of public-private partnership. The idea and model of public-private partnership is one of the current alternatives that allow us to solve the problems of handling COVID-19 in DKI Jakarta Province. Yusuf et al. (2006) stated that public-private partnership (PPP) is a collaboration that involves actors or stakeholders from business, non-profit, and government organizations gathering in the same forum to make a consensus. Therefore, publicprivate partnership is an analytical tool in this research because it discusses partnerships explicitly to solve public problems involving various actors from the public and private sectors.

According to Yusuf et al. (2006), there are 3 (three) success factors for public-private partnerships, namely, process factors, partner factors, and structural factors. The process factor is identifying issues that are considered to be addressed before setting up a partnership and building a solid foundation for successful privatization through public-private partnerships. At the same time, the partner factor is related to choosing the right partner and essential issues for developing relationships with these partners. Finally, the structural aspect is the clarity of outlining roles and responsibilities, adopting performance-based contracts, and enforcing 
effective contract accountability.

The cooperation model between the government and the private sector can be in the form of work contracts, tenders for the supply of goods or services, or business process outsourcing (OECD, 1997). There is a public-private partnership model that includes:

1. Service Management

2. Management Contract

3. Lease Contract

4. Build Operate Transfer

\section{Concession Contract}

In the partnership carried out by the DKI Jakarta Provincial Government, the specific role division of each party involved must be carried out as a Build-Operate-Transfer (BOT) model, namely the private sector partner must finance and create a project in collaboration with the DKI Jakarta Provincial Government and then transfer ownership of the facility to the DKI Jakarta Provincial Government. Yusuf et al. (2006) define the Build, Operate Transfer (BOT) model as a public-private partnership approach. The public sector contracts with the private sector to construct, operate and maintain a facility or project. Meanwhile, the government is responsible for project financing and design and regulatory clarity. In this model, the private partner has ownership of the project for the duration of the contract, with the right to return to the government at the end of the contract.

The efficiency of the way the private sector works, the quality of their human resources, and the speed with which technology is adopted are often why the government needs to involve the private sector. For example, the DKI Jakarta Provincial Government collaborates with the private sector, Agile Innovation Labs, and the non-profit Human Initiative to procure the Mobile Labs Test for COVID-19. The problem with this partnership is that the government's role is more dominant, in this case, the DKI Jakarta Provincial Government. In fact, in the concept of public-private partnership offered by Yusuf et al. (2006), the role of the private sector is very much needed in accelerating the handling of problems, such as the COVID-19 problem. So far, from the description of the partnership efforts above, the specific role division of each party has not been maximized. So this research was conducted within the framework of the title Public-Private Partnership in Handling Corona Virus Disease 2019 (Covid-19) in DKI Jakarta Province.

\section{Methods}

This research method uses a descriptive method with a qualitative approach. Numbers cannot measure this research because this study seeks to describe and reveal the partnership between stakeholders in handling the 2019 coronavirus disease (Covid-19) in DKI Jakarta Province. In the study entitled "Public-Private Partnership in Handling Corona Virus Disease 2019 (Covid-19) in DKI Jakarta Province," this study used observation, interview, and documentation data collection techniques. Observations were made on both objects, namely the government and non-profit institutions. In this case, the government's observation is the observation made to the DKI Jakarta Provincial Government inviting the private sector and non-profit institutions to form partnerships in handling COVID-19. While observations on the private sector are made on companies engaged in the health sector that have partnered with the DKI Jakarta Provincial Government in managing COVID-19. Observations focused on the 
partnership results between the DKI Jakarta Provincial Government and the private sector, Agile Innovation Labs and the non-profit organization Human Initiative.

While conducting in-depth interviews, researchers prepare interview guidelines to be used as relevant data sources in the study. This study conducted in-depth interviews with informants, namely the DKI Jakarta Regional Secretariat Cooperation Bureau, the DKI Jakarta Province Covid-19 Handling Task Force, Human Initiative (HI), and Agile Innovation Labs (Ai Labs). As for the preparation of questions in the interview guide using indicators derived from theory (Yusuf et al. 2006), namely: Process Factors; Partner Factors (Partner Factors); Structural Factors (Structural Factors).

The documents used here are in the form of minutes and cooperation agreements between the DKI Jakarta Provincial Government and non-profit institutions and the private sector in handling the Corona Virus Disease 2019 (Covid-19) in DKI Jakarta Province. The documentation in this study is: Peraturan Daerah Nomor 2 Tahun 2020 tentang Penanggulangan Corona Virus Disesase 2019 (Covid-19), Peraturan Gubernur Nomor 3 Tahun 2021 tentang Peraturan Pelaksanaan Peraturan Daerah Nomor 2 Tahun 2020 tentang Penanggulangan Corona Virus Disease 2019 (Covid-19), Keputusan Gubernur Nomor 360 Tahun 2020 tentang Gugus Tugas Percepatan Penanganan Coronavirus Disease 2019 (Covid-19) Provinsi DKI Jakarta, Instruksi Sekretaris Daerah Provinsi DKI Jakarta Nomor 35 Tahun 2020 tentang Pelaksanaan Kolaborasi Sosial Berskala Besar, The manuscript of the Cooperation Agreement (PKS) for the Procurement of the Covid-19 Mobile Labs Test between the DKI Jakarta Provincial Government, Human Initiative, and Agile Innovation Labs.

In this study, the data collection technique used was purposive sampling. A purposive sampling technique is a sampling technique of data sources with specific considerations. In other words, the sample is taken based on research needs. The informants of this research are (1) the Head of the Regional Cooperation Division of DKI Jakarta Regional Cooperation Bureau, (2) the Head of the General Section of the DKI Jakarta Provincial BPBD Secretariat, (3) the Public Relations Manager of Human Initiative, and (4) the Initiator of Agile Innovation Labs (Ai-Labs). These informants are the primary informants in this study. The data analysis process carried out in this study includes several steps, including data reduction, namely the process of selecting, simplifying, focusing, and converting rough data into field notes. The next step is to present the data (data display). Presentation of data is the collection of data or information in an organized manner, allowing concluding and taking action. Finally, triangulation was carried out with the source to meet the validity of the research data. According to Moleong (2006), Triangulation is a data checking technique that utilizes data checking as a comparison against the data. Furthermore, Lexy J. Moleong said that the most widely used triangulation technique was other sources.

\section{Results and Discussion}

There are various types of collaboration in handling Covid-19 in DKI Jakarta Province. One of which is collaboration in the health sector, namely by increasing health facilities such as laboratory networks to support Covid-19 testing capabilities. This collaboration is carried out with the central government and private parties that have laboratories with Bio-Safety Level-2 (BSL-2) standards in accordance with the Circular Letter of the Minister of Health Number 234 of 2020 concerning Guidelines for the Examination of the Covid-19 Polymerase Chain Reaction (PCR) Test. 
Figure 2

Protoype Mobile Lab PCR Test Covid-19.

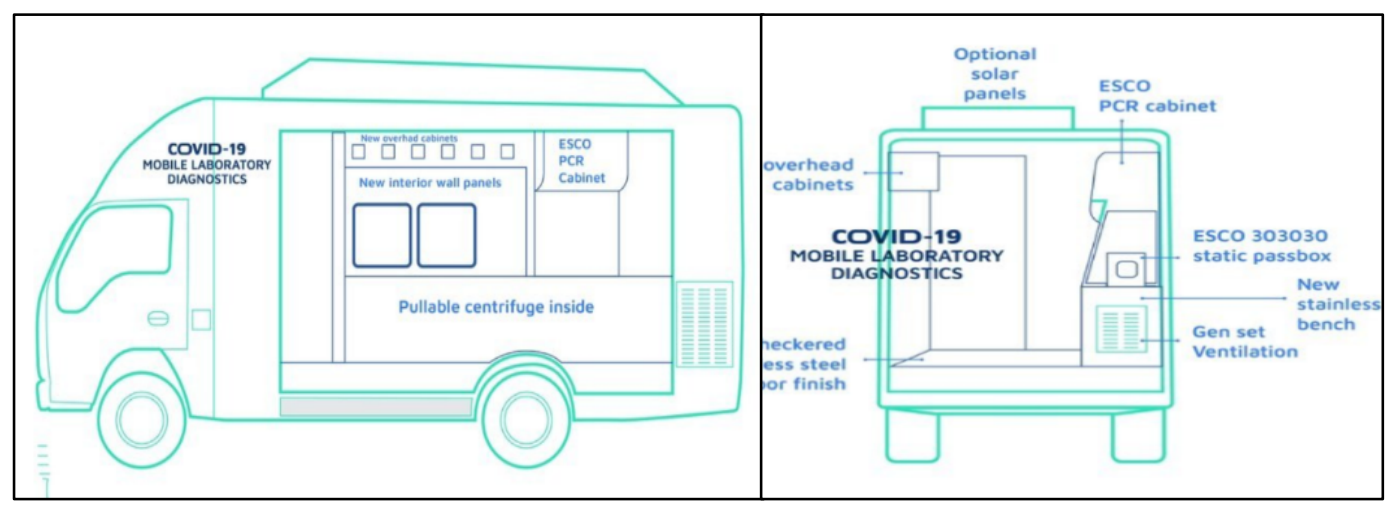

Source: Agile Innovation Labs 2020 Portfolio Document

The partnership in handling Covid-19 in DKI Jakarta Province in the health sector has been demonstrated by increasing health facilities, namely the collaboration in the Mobile Lab PCR Test for Covid-19. This procurement results from collaboration from the private sector, including non-profit institutions and companies in the health sector. The parties are Human Initiative and Agile Innovation Labs (Ai-Labs). In the results of the observations, it was found that there was a specific division of roles for each party. The non-profit organization Human Initiative acts as the party that raises funds. At the same time, the Agile Innovation Labs company is the party that designs and makes the Mobile Lab PCR Test Covid-19.

The benefit of the availability of the Mobile Lab PCR Test Covid-19 is that it will add standard Bio-Safety Level-2 (BSL-2) laboratory facilities in DKI Jakarta Province to meet the community's needs regarding Covid-19 tests. With this facility, testing capacity in DKI Jakarta Province will also increase and become a facility for close contact tracing or tracing. In addition, the existence of the Covid-19 Mobile PCR Test will also be beneficial for other medical purposes, such as biological research, clinical testing, and even analysis of high-risk virus epidemics such as A-H1N1 Swine Flu H5N1 Avian Flu or Bird Flu, Salmonella, and others.

\section{Process Factors}

The imbalance of resources underlies the occurrence of a public-private partnership between the DKI Jakarta Provincial Government and the private sector. The DKI Jakarta Provincial Government realizes that it cannot move independently. Therefore, through the Governor of DKI Jakarta, Anies Rasyid Baswedan, the DKI Jakarta Provincial Government invites all stakeholders to handle COVID-19 in DKI Jakarta Province. This is in accordance with the results of interviews conducted with the informant as the Head of the Third Party Cooperation Bureau of the DKI Jakarta Provincial Secretariat, namely that since COVID-19 was announced by WHO as a pandemic and then reported by President Joko Widodo, some Indonesian citizens were exposed to the virus. In response to COVID-19 in Indonesia, the DKI Jakarta Provincial Government immediately responded in various ways. In accordance with the direction of the Governor of DKI Jakarta, Anies Baswedan, the handling of the pandemic must be with the Penta helix scheme. With this scheme, of course, the DKI Jakarta Provincial Government invites experts, academics, media, the private sector, and the public to work together in handling COVID-19 in DKI Jakarta Province so that these five elements must be 
present in a partnership effort.

What is meant by responding to the COVID-19 pandemic in various ways is to invite all parties to assist the DKI Jakarta Provincial Government in handling COVID-19. The parties consist of national and multi-national entrepreneurs, non-profit institutions, and the community.

The DKI Jakarta Provincial Government carries out various types of partnerships with parties who want to help in handling COVID-19. Based on the results of the interview with the informant as the Head of the Third Party Cooperation Division of the Regional Cooperation Bureau of the DKI Jakarta Provincial Secretariat, one of the partnerships carried out focuses on the health sector by optimizing $3 \mathrm{~T}$ capabilities, namely testing, treatment, and tracing. This partnership is carried out with private parties engaged in the health sector, such as technology research companies that provide Covid-19 swab test laboratories.

More specifically, one of the non-profit organizations registered with the United Nations (UN) world organization, namely the Human Initiative, has participated in partnering in handling COVID-19. The Human Initiative has a role, one of which is as an aggregator institution and a humanitarian agency and is moved to join a partnership because it realizes that in overcoming a disaster, the participation of all parties is needed. The DKI Jakarta Provincial Government is no longer the dominant party in overcoming COVID-19, but there needs to be a thorough division of tasks among all parties who want to partner. This is in accordance with the results of interviews that have been conducted with the informant as the Public Relations Manager of the Human Initiative, namely that, as a non-profit institution, the Human Initiative feels responsible for helping the DKI Jakarta Provincial Government because when facing a disaster or emergency, the government cannot be the most dominant. His job. In the health sector, collaboration is carried out, including the procurement of a mobile lab in partnership with Agile Innovation Labs.

Furthermore, in the health sector, based on the results of interviews with informants as Initiators of Agile Innovation Labs, the primary key to handling COVID-19 is to improve the testing ability of each specimen. Increased testing can be done by adding health facilities to speed up the results of the COVID-19 test for each person who is sampled. Therefore, additional laboratories are needed to assist the DKI Jakarta Provincial Government in improving testing capabilities. According to the results of interviews conducted with Agile Innovation Labs Initiator Informants, one of the keys to overcoming the COVID-19 pandemic is to accelerate sample testing capabilities. Therefore, Ai Labs is trying to create a mobile lab. Initially, Ai Labs did not have the funds to build a mobile lab, so empathy mapping and partnerships with various parties were needed.

From the interview results above, it can be seen that a company engaged in the health sector, namely Agile Innovation Labs, has the technology to create additional health facilities, such as a mobile lab network, also known as the Mobile Lab. However, because this company has a limited budget for building a lab with a biosafety level of 2 (BSL-2), collaboration with other parties is required to find donors to create an ongoing lab network in DKI Jakarta Province.

The leadership by the regional government must, of course, be in line with the central government, especially in handling disasters that have affected almost all sectors, namely the COVID-19 pandemic. Each local government has political will in accordance with the direction of regional development determined by each leader. DKI Jakarta Province has become an area that prioritizes partnerships as a foundation for overcoming various problems in its scope. As 
stated in the interview with the informant as the Head of the Third Party Cooperation Bureau of the DKI Jakarta Provincial Secretariat, namely that the city of Jakarta, since the leadership of Governor Anies Baswedan, has carried the vision of Jakarta as a City of Collaboration. This means that, from the very beginning, the Governor himself initiated that Jakarta, in solving problems, must cooperate with certain parties. Jakarta has also developed the City 4.0 concept, which creates a system as a provider and as a co-creator who can collaborate with all elements to solve a problem such as the COVID-19 pandemic. So, all programs for handling COVID-19 are oriented towards Jakarta, "A City of Collaboration," which is the Governor's vision and mission.

From the interview results, it can be seen that since the beginning of his leadership, DKI Jakarta Governor Anies Rasyid Baswedan has initiated the concept of collaborationpartnership. This initiative is contained in one of the Governor's visions, namely to realize the DKI Jakarta Province into a Jakarta City of Collaboration. Thus, efforts to handle COVID-19 in DKI Jakarta Province are also based on partnerships built by various parties.

Furthermore, based on the results of in-depth interviews that have been conducted with the informant as the Head of the Third Party Cooperation Division, the Regional Cooperation Bureau of the DKI Jakarta Provincial Secretariat, namely that the Governor directs that all problematic sectors must be resolved by parties who are experts in their fields, Involving the private sector or the public, the DKI Jakarta Provincial Government invites all parties to a forum. Various aggregator institutions such as the ACT, PMI, Human Initiative, Bazis Baznas, and others are included in the forum. In addition, the DKI Jakarta Provincial Government also invited all companies in the DKI Jakarta area. In the meeting, the Governor directly conveyed the intent and purpose of the importance of such cooperation. So naturally, many parties want to collaborate with the DKI Jakarta Provincial Government. During the COVID-19 pandemic, there have been 170 Memorandums of Understanding (MoU) in cooperation with other parties.

Based on the interview results above, it can be seen that the Governor himself is promoting partnership measures with the public and private parties, such as non-profit institutions, in handling COVID-19 in DKI Jakarta Province. At the beginning of the partnership process, the Governor created a forum to introduce aggregator institutions to national and multi-national companies. Furthermore, as a leader in handling COVID-19 in his area, DKI Jakarta Governor Anies Rasyid Baswedan initiated collaborative disaster management by prioritizing any problems in sectors affected by the COVID-19 pandemic resolved together with experts in their fields.

The public-private partnership process factors in handling COVID-19 in DKI Jakarta Province has been seen from the efforts of the Governor who participated in inviting parties to partner. This makes it one of the crucial factors in the success of a public-private partnership. The Governor's leadership role demonstrated in the effort to build this partnership is to embrace, empower, and involve stakeholders and mobilize them to advance the partnership.

\section{Partner Factors}

The history of cooperation in disaster management between the DKI Jakarta Provincial Government and various parties has previously occurred. The collaboration occurred during the Avian Influenza epidemic, the SARS virus, and dengue fever in the DKI Jakarta Province area, which was also based on the principle of partnership. The Provincial Government of DKI Jakarta invites all parties from the private sector and the community to join in partnership. The history of involvement of other parties in handling infectious disease disasters has resulted in a good and sustainable partnership to date. Still, there is no history of collaboration in addressing contagious disease disasters. As big and as wide as the handling of COVID-19 now, The 
informant explained this as the Head of the General Section of the DKI Jakarta BPBD Secretariat, who said that previous collaborations had been carried out with the private sector and the public. Still, in this collaboration to handle Covid-19, the scale of involvement of various parties was broader because the spread of the Covid-19 disease was a disaster that took place quickly and thoroughly in different regions in Indonesia.

As for the history of partnerships that have been carried out between the DKI Jakarta Provincial Government and non-profit institutions such as the Human Initiative, based on interviews that have been conducted with Informants as Public Relations Manager of the Human Initiative, both parties have previously established partnerships in the field of entrepreneurship research in the Jak program, entrepreneurs In addition, partnerships are also carried out in the form of technical matters such as the distribution of assistance for social activities in the DKI Jakarta Province.

So we can see from the results of the observations above that the history of cooperation between stakeholders has happened before and uses this as social capital to continue partnership efforts that will be carried out in the future. The partnership effort in handling Covid-19 is a continuation of a history of successful cooperation in the previous partnership, which has also created a high level of trust between the parties, resulting in a good cycle of cooperation in the handling of Covid-19 partnerships in DKI Jakarta Province. The past collaboration history makes the parties want to start partnership efforts again.

The most essential factor in selecting private-sector partners is that the selection process is carefully designed and implemented consistently. The purpose of the selection process is to pay attention to the track record of good performance of every private party who wants to be involved in a partnership with the DKI Jakarta Provincial Government. This is further strengthened by the commitment between stakeholders in the partnership process. This commitment can be seen through regular meetings or meetings to evaluate the partnership process. If there is an evaluation at one of the internal agencies of the provincial government or from the private sector, then the next step is to give a warning to that party.

In addition to holding regular meetings, the commitment between the parties involved in the partnership can also be seen from the initial goal of the collaboration in handling COVID19, namely the humanitarian aspect. The partnership program between the parties was created because it is based on helping people affected by the COVID-19 pandemic. This is based on the results of interviews that have been conducted with the informant as the Head of the Third Party Cooperation Division of the Regional Cooperation Bureau of the DKI Jakarta Provincial Secretariat, namely that in cooperation in handling COVID-19 in DKI Jakarta Province, the humanitarian aspect is the driving force for the parties to continue to commit together. The DKI Jakarta Provincial Government is looking for the reason that can be accepted by all parties so that it becomes a basis for the parties to continue to commit. The sense of humanity working together to help each other is a commitment to other parties working together amid the COVID19 pandemic.

This is also in line with the Human Initiative, which states that if a difference in commitment is found in the middle of the partnership process, it will be resolved with a solution that all parties can accept by returning to the original purpose of the partnership, which is to partner to provide benefits to communities affected by the COVID-19 pandemic.

Thus, it can be seen that there is a commitment between the parties involved in the publicprivate partnership process to handle COVID-19 in DKI Jakarta Province through regular meetings as well as the initial goal of establishing a partnership. However, regular meetings held by the DKI Jakarta Provincial Government with the Human Initiative and Agile Innovation 
Labs companies should be monitored by real-time system-based performance reporting. It is intended that the evaluations carried out at these regular meetings are based on solid reasons and can be controlled to achieve the expected results.

\section{Structural Factors}

The parties involved feel that they are responsible for handling COVID-19. This is one of the reasons for the parties to participate in the partnership in addressing COVID-19 in the DKI Jakarta Province. As in the results of interviews carried out with informants as Initiators of Agile Innovation Labs, collaboration is a must in disaster management. In the science of innovation, the main strength is cooperation or collaboration. It does not mean that the person who has the idea is the one who is most able to make it happen. In the process of realizing it, they will be increasingly aware that in every collaboration or collaboration effort, there are parties who have their respective expertise who understand better. The capabilities of the parties are limited, so cooperation is needed. Of course, each party who joins will provide strength for the whole team in this partnership. The basis of Ai Labs' wanting to do a partnership is that they believe many parties will cumulatively strengthen the capabilities of the Mobile Lab procurement project, such as enhancing relations in the social, economic, and legal fields, so that the partnership results run smoothly and successfully to completion.

From the interviews above, it can be seen that partnership efforts in disasters are a must and need to be realized. Each party involved in the collaborative handling of COVID-19 will play a role according to their respective abilities to be involved in the partnership so that the more parties involved, the stronger the partnership effort will be.

This is also in line with the results of interviews conducted with the informant as the Head of the General Section of the DKI Jakarta BPBD Secretariat, which showed that the role of each party involved in the COVID-19 handling partnership is not the same because each party has different tasks, functions, and abilities. This is also because the existing governance mechanisms in the DKI Jakarta Provincial Government have various main tasks and functions at each agency so that the contribution form of each party is different.

Private parties who want to partner in handling COVID-19 in DKI Jakarta Province can assist in any form. The Task Force for Handling Covid-19 does not have specific criteria for screening collaborators who want to assist in handling Covid-19. Hence, institutions and community groups, or even individuals in the community, are very welcome to contribute to the Covid-19 handling partnership. The observations also found that there was a specific division of roles between each of the parties involved. For example, the non-profit organization Human Initiative acts as the party that raises funds using the crowdfunding mechanism for the community and invites international humanitarian aid funding agencies (International Funding) and the NAMA Foundation to provide aid funds as a form of support for the procurement program. Mobile Lab PCR Test, Covid-19. Meanwhile, the Agile Innovation Labs company is the party that designed and made the Mobile Lab PCR Test Covid-19, which will later be submitted to the DKI Jakarta Provincial Government through the DKI Jakarta Provincial Health Office so that it can be operated to meet the needs of Covid-19 testing in DKI Jakarta Province.

A statement from the informant as the Head of the General Section of the DKI Jakarta BPBD Secretariat said that although currently, the ranks of the DKI Jakarta Provincial Government are facing the most challenging situation or crisis due to the COVID-19 pandemic, his party admitted that all human resources in DKI Jakarta Provincial Government agencies are still consistent with their primary duties and functions because maintaining this consistency is a form of service to the state and society. 
In partnership with the private sector, the Human Initiative admits that collaboration with the provincial government as mandated in the Cooperation Agreement (PKS) has obstacles in maintaining the consistency of the agreement. Obstacles faced include, among others, the progress of the procurement of Mobile Labs Test Covid-19 not being in accordance with the deadline that has been set due to dynamic regulatory changes to adjust to the conditions of the Covid-19 pandemic. Therefore, monitoring and evaluation are needed as a reminder of the rights and obligations of each party that have been stated in the Cooperation Agreement (PKS). This is based on the results of interviews that have been conducted with the informant as the Public Relations Manager of the Human Initiative, namely that in every Cooperation Agreement (PKS), nothing is perfect as a whole.

More specifically, the obstacles faced in the implementation of the Cooperation Agreement (PKS) with the private sector include the change of provincial government officials during the collaboration process because the transfer of knowledge between old and new officials regarding the conditions of the collaboration process did not go well, thus causing the partnership process hampered. This is based on the results of interviews that have been conducted with the informant as the Head of the Third Party Cooperation Division of the Regional Cooperation Bureau of the DKI Jakarta Provincial Secretariat, namely that the obstacle in maintaining the consistency of the partnership is the change of officials, causing a lack of transfer of knowledge between replaced officials and making the partnership process also hampered. Second, there are coordination difficulties due to the pandemic period. The parties initially met face to face to maintain consistency from the parties involved, but now it has changed to virtual.

As can be seen from the interview results above, another obstacle arises because of the difficulty of the immediate coordination process due to the implementation of social restrictions. This means coordination with the private sector cannot be done face-to-face but through a virtual online mechanism. As the representative of the provincial government, the Regional Cooperation Bureau admits that the implementation of the Cooperation Agreement (PKS) is more consistent if the coordination is carried out directly.

Finally, there have been temporary successes achieved in the private partnership process. Such success is not the result of the partnership process but a critical outcome to build the momentum to lead to a successful partnership. For example, the collaboration in handling COVID-19 in DKI Jakarta Province, the temporary success can be seen through improving health facilities, such as the procurement of mobile labs. There are three units of the Covid-19 Mobile Lab PCR Test, which are mobile health laboratories. This laboratory is equipped with Polymerase Chain Reaction (PCR) equipment and has a Bio-Safety Level-2 (BSL-2) standard, so it can check whether someone has been infected with Covid-19. This is based on the results of interviews that have been carried out with Informants as Agile Innovation Labs Initiators, namely the progress of the Ai Labs collaboration has achieved the provision or grant of three units of Mobile Lab PCR Test Covid-19 to the DKI Jakarta Provincial Government with the ability to detect someone who has been infected with the Covid-19 virus, which only takes four (four) hours per patient sample, so that the results of the check can be known by the patient no later than one day. With the current number of samples being examined, as many as 100 samples for each mobile lab and gradually up to 200 samples per day for each mobile lab.

As a form of build-operate-transfer (BOT), as for the script of the handover of the grant from the Human Initiative to the DKI Jakarta Provincial Health Office in the partnership for the procurement of 3 (three) units of Mobile Lab PCR Test Covid-19 BSL-2, there are various types of equipment. The Mobile Lab supports health, which can be seen in detail in the table below: 
Table 1

Covid-19 Mobile Lab PCR Test Support

\begin{tabular}{|c|c|c|}
\hline No. & Submitted Type & Volume \\
\hline 1. & BSL-2 Laboratory Mobile Vehicle & 3 Units \\
\hline 2. & BSC Class II TypeA2 & 3 Units \\
\hline 3. & Maxwell RSC 16 Sample & 3 Units \\
\hline 4. & $\begin{array}{l}\text { Ultra-Low Freezer } \\
\bullet \quad 80 \text { Refrigerator }\end{array}$ & 3 Units \\
\hline 5. & Real-Time MyGO & 3 Units \\
\hline 6. & Refrigator4C & 3 Units \\
\hline 7. & Refrigerator Freezer20C & 3 Units \\
\hline 8. & PCR Cabinet & 6 Units \\
\hline 9. & Micropipette (1 Set) & 3 Units \\
\hline 10. & Autoclave & 3 Units \\
\hline \multirow[t]{4}{*}{11.} & DLAB Covid Packages & \\
\hline & - Mini centrifuge & 6 Units \\
\hline & - VortexMixer & 3 Units \\
\hline & - Dry bath & 3 Units \\
\hline
\end{tabular}

Source: News of the Launching of the Mobile Lab PCR Test for COVID-19 BSL-2

The partnership in the Covid-19 Mobile Lab PCR Test procurement has shown results, namely by donating 3 (three) units to the DKI Jakarta Provincial Government to be used as a satellite laboratory belonging to the DKI Jakarta Provincial Health Office. Therefore, based on the data previously described, it can be seen that the public-private partnership relationship in handling COVID-19 in the DKI Jakarta Province, carried out by the DKI Jakarta Provincial Government, the Human Initiative, and the Agile Innovation Labs company has seen structural factors in the partnership process.

\section{Conclusion}

Public-private partnership relations in handling COVID-19 in DKI Jakarta Province can be seen through three public-private partnership factors consisting of process factors, partner factors, and structural factors. The public-private partnership that has been established does not prioritize profit-oriented orientation, both from the DKI Jakarta Provincial Government and the private sector itself. This is because the process factor shows that all parties have the capacity, organization, status, or resources to participate equally with other parties, namely partnerships based on humanitarian aspects. An exciting finding obtained in this factor is that the leader facilitates group dynamics, ensures broad influence, and promotes broad and active participation in the partnership process. Therefore, in handling COVID-19 in DKI Jakarta Province, the leader's role is significant in determining the course of the partnership relationship. Therefore, existing leadership will play an essential role in supporting the partnership process and influencing the outcomes.

Furthermore, the public-private partnership relationship in the partner factor shows that the history of successful cooperation in the past can create social capital and a high level of 
trust to produce a good partnership cycle so that the partnership shows high interdependence among stakeholders. The commitment of the parties involved in the public-private partnership process in handling COVID-19 in the DKI Jakarta Province through regular meetings and the initial goal of establishing a partnership.

Lastly, the structural factors show that the handling of COVID-19 in DKI Jakarta Province has also built mutual trust between interested parties. This trust can be seen through the temporary success of the collaboration between the DKI Jakarta Provincial Government, the private sector, and the community. The division of specific roles for each party involved has been carried out as a form of Build Operate Transfer (BOT). Private partners finance and manufacture the Covid-19 Mobile Lab PCR Test and then transfer ownership of the facility to the DKI Jakarta Provincial Government.

\section{References}

Abbas, M. Y. (2018). Public Private Partnership Dalam Pembangunan dan Pengelolaan Suncity Plaza Sidoarjo. Program Studi Ilmu Administrasi Negara, 1-9.

Ansell, C., \& Gash, A. (2007). Collaborative Governance in Theory and Practice. Journal of Public Administration Research and Theory, 543-571.

Ansell, C., \& Gash, A. (2017). Collaborative Platform as a Governance Strategy. Journal of Public Administration Research and Theory, 1-17.

Brinkerhoff, D. W., \& Brinkerhoff, J. M. (2011). Public-Private Partnership: Perspective On Purposes, Publicness, and Good Governance. Public Administration and Development, 2-14.

Donahue, \& Z., J. R. (2011). Collaborative Governance (Private Roles for Public Goals in Turbulent Times). New Jersey: Princeton University Press.

Ismoati, M. (2016). Kajian Urgensi Public Private Partnership di Kota Bandung. TRANSPARANSI Jurnal Ilmiah Ilmu Administrasi, 141-149.

Kang, S., Mulaphong, D., Hwang, E., \& Chang, C.-K. (2018). Public-private partnerships in developing countries: Factors for success. International Journal of Public Sector Management.

Mahmudi. (2007). Kemitraan Pemerintah Daerah. Kajian Bisnis dan Manajemen, 53-67.

Moleong, L. J. (2011). Metode Penelitian Kualitatif. Bandung: PT Remaja Rosdakarya.

Mona, N. (2016). Mekanisme Contagion dalam Jaringan Sosial. Jurnal Sosial Humaniora Terapan.

Mona, N. (2020). Konsep Isolasi Dalam Jaringan Sosial Untuk Meminimalisasi Efek Contagious (Kasus Penyebaran Virus Corona Di Indonesia). . Jurnal Sosial Humaniora Terapan, 117-124.

OECD. (2012). Competitive Neutrality: A Compendium of OECD Recommendations, Guidance and Best Practices. The Organisation for Economic Co-operation and Development.

Sahya. (2015). Metode Penelitian Administrasi. Surakarta: Pustaka Setia. 
Sciulli, N. (1998). Competitive Tendering and Contracting in the Public Sector: A Survey. International Journal of Economics of Business, 439-453.

Sudarmo. (2006). Perspectives on Governance: Towards and Organizing Framework For Collaborative and Collective Actions. Jurnal Spirit Publik, 113-120.

Sudarmo. (2011). Isu-isu Administrasi Publik dalam Perspektif Governance. Solo: SmartMedia.

Utama, D. (2013). Prinsip dan Strategi Penerapan "Public Private Partnership" Dalam Penyediaan Infrastruktur Transportasi. Jurnal Sains dan Teknologi Indonesia.

Wang, Z., Qiang, W., \& Ke, H. (2020). A Handbook of 2019-nCoV Pneumonia Control and Prevention. Hubei: Hubei Science and Technologi Press.

Xiong, W., Chen, B., Wang, H., \& Zhu, D. (2018). Governing public-private partnerships: A. Research \& Evaluation, 1-17.

Yusuf, J.-E. (., Wallace, C. Y., \& M. H. (2006). Privatizing Transportations through PublicPrivate Partnership: Definitions, Models, dan Issues. Kentucky: Kentucky Transportation Center. 